\title{
First Record of Dendrolimus pini Outbreak on Aleppo Pine in Croatia and Severe Case of Population Collapse Caused by Entomopathogen Beauveria bassiana
}

\author{
Marta Matek ${ }^{1}$, Milan Pernek ${ }^{1 *}$
}

(1) Croatian Forest Research Institute, Division for Forest Protection and Game Management, Cvjetno naselje 41, HR-10450 Jastrebarsko, Croatia

\begin{abstract}
Citation: MATEK M, PERNEK M 2018 First Record of Dendrolimus pini Outbreak on Aleppo Pine in Croatia and Severe Case of Population Collapse Caused by Entomopathogen Beauveria bassiana. Southeast Eur for 9 (2): 91-96. DOI: https://doi. org/10.15177/seefor.18-17

Received: 21 Nov 2018; Revised: 12 Dec 2018; Accepted: 14 Dec 2018; Published online: 22 Dec 2018
\end{abstract}

\begin{abstract}
Background and Purpose: The pine-tree lappet moth, Dendrolimus pini, is a widely distributed pest in Europe that can cause serious needle defoliation on pines, with outbreaks occurring over large geographical areas. In Croatia the presence of $D$. pini was recorded only in the continental part, but not in a high level of abundance, and the outbreak of the population has never been recorded so far.

Materials and Methods: In autumn 2014 an unexpected and complete defoliation on Aleppo pine (Pinus halepensis Mill.) occurred in the vicinity of Skradin, near Šibenik, and was followed by defoliation in summer and autumn 2017 in Telašćica Nature Park, Dugi otok. Infested areas were inspected and overwintering larvae in soil surface were counted in order to estimate the population and assess whether the critical number of the population has been exceeded. Specimens were collected and transferred to the Laboratory for Entomological Analysis in the Croatian Forest Research Institute for further laboratory analysis.

Results: Since more than 10 larvae per $\mathrm{m}^{2}$ of soil surface were found, it was concluded that an outbreak occurred at both localities. In both cases natural antagonists played an important role in lowering the pest population. In Skradin, entomopathogenic fungus Beauveria bassiana that occurred on the overwintering larvae broke the pest population, and in Dugi otok it was recorded, but to a much lesser extent and in combination with Drino inconspicua parasitoid. In both cases pines recovered very well in the following spring, with some bark beetle attacks mostly at the edge of the forest.

Conclusions: The outbreaks of $D$. pini resulting with a total defoliation of Aleppo pine stands, and the fact that they occurred in the Mediterranean region which is not an optimal area for its appearance, makes these events unusual. Also, this is the first record of $D$. pini population breakdown by some antagonist.
\end{abstract}

Keywords: antagonists, Drino inconspicua, Mediterranean, overwintering larvae, pine-tree lappet moth, Pinus halepensis

\section{INTRODUCTION}

The pine-tree lappet moth, Dendrolimus pini (L.) (Lepidoptera, Lasiocampidae), is a widely distributed pest in Europe $[1,2]$. Its primary host is Pinus sylvestris L., but larvae can also feed on the needles of other species, mainly pines [3].

In July, after mating, each female lays 150-250 eggs on pine needles, twigs or bark in the canopy. Larvae begin to hatch within 1-3 weeks and start with autumn feeding which lasts until the occurrence of first frost, when they move down into the soil to find a proper site for hibernation. In spring, after overwintering, they climb into tree crowns where they feed on needles as well as the bark and buds of young shoots $[2,4]$. One $D$. pini caterpillar can consume between 600 and 1000 pine needles through its development [5].

Spring feeding has a more damaging effect than the autumn one, and there are several reasons for that. First, the larvae at this stage are much bigger and consume a larger amount of needles. The second reason is that after complete defoliation, larvae can devour new needles that pines developed, and sometimes even parts of green shoots. This significantly weakens the vitality of the host, resulting in 
tree's dieback or the attack of secondary pests, most often bark beetles. Because of all this, it is extremely important to forecast a spring population, which is done by controlling the number of overwintering larvae (soil inspection and counting of hibernating larvae on a specific surface amount). Based on the empirical critical numbers, the answer is given whether suppressive measures are needed or not.

D. pini can cause serious needle defoliation, often followed by tree death, and its outbreaks can occur over large geographical areas [6]. It particularly happens at 30 to 60-year-old even-aged monocultures on warm and dry climatic conditions, where precipitation does not exceed 600 $\mathrm{mm}[7,3]$.

First reports about mass outbreaks in Europe have been recorded at the beginning of the $18^{\text {th }}$ century. Many areas dominated by Scots pine in Eastern and Central Europe have regular outbreaks of $D$. pini [1]. For example, between the year 1700 and 1929, 77 outbreaks were recorded in Germany [8], and several outbreaks have been documented since 1791 in Poland where more than 200000 hectares were treated between 1946 and 1995 in order to control this insect [2]. In the period from 1812 to 1816 about 5000 hectares were defoliated in Norway [9], with the outbreak recurring on 600 ha in the same area 85 years later [10,11]. From 1938 to 40, an area of 700 ha, dominated by Scots pine, was defoliated in west central Sweden [12]. In 2012, on a small island called Furuskär in the Stockholm archipelago a severe D. pini outbreak was recorded where the largest parts of the island were heavily defoliated [2].

In Croatia, D. pini outbreaks have never been recorded so far, so unexpected total defoliation it caused on Aleppo pine (Pinus halepensis Mill.) and the fact it occurred at localities in the Mediterranean region where its presence has never been recorded make this events unusual.

\section{MATERIALS AND METHODS}

\section{Outbreak in Skradin}

In autumn 2014, several Aleppo pine stands in the vicinity of Skradin, near Šibenik, were seriously damaged by $D$. pini larvae feeding on needles. After inspection of an infested area, around 400 ha were found to be attacked, 20 ha of these being totally defoliated (Figure 1).

The first step was to estimate the population density, in order to decide whether suppressive measures are needed. Estimation of the population was conducted by soil surface inspection in order to find and count the hibernating larvae. The number of larvae per square meter of soil surface was assessed within the wooden frames $33.3 \times 33.3 \mathrm{~cm}$ in size. The density of larvae was assessed by 108 samples (via wooden frames) with the minimum of $5 \mathrm{~m}$ distance between each, representing in total $12 \mathrm{~m}^{2}$ of sampled surface. The critical population level number for this pest used in Central Europe is 10 larvae per $\mathrm{m}^{2}$ (Dr. Katrin Möller, Brandenburg State Forestry Center of Excellence, pers. comm. in 2014).

Also, during the process of population assessment a large number of dead larvae was found. There were 306 collected larvae that were transferred to the Laboratory for Phytopathology Analysis of the Croatian Forest Research Institute for further laboratory inspection. To reveal the cause of death, each dead larva was placed on a moist filter paper disk in a sterile Petri dish to induce the potential sporulation of fungi. The larvae placed into a moist chamber were incubated at $24 \pm 1{ }^{\circ} \mathrm{C}$, and a photoperiod $\mathrm{L}: \mathrm{D}=16: 8$. After 3-4 days, fungi were isolated from each caterpillar on PDA medium, and inoculated Petri dishes were stored at controlled conditions described above. Within 2-3 weeks, all the cultures were microscopically examined. After morphological confirmation, the cultures were sent to Marta Wrzosek, Department of Molecular Phylogenetics

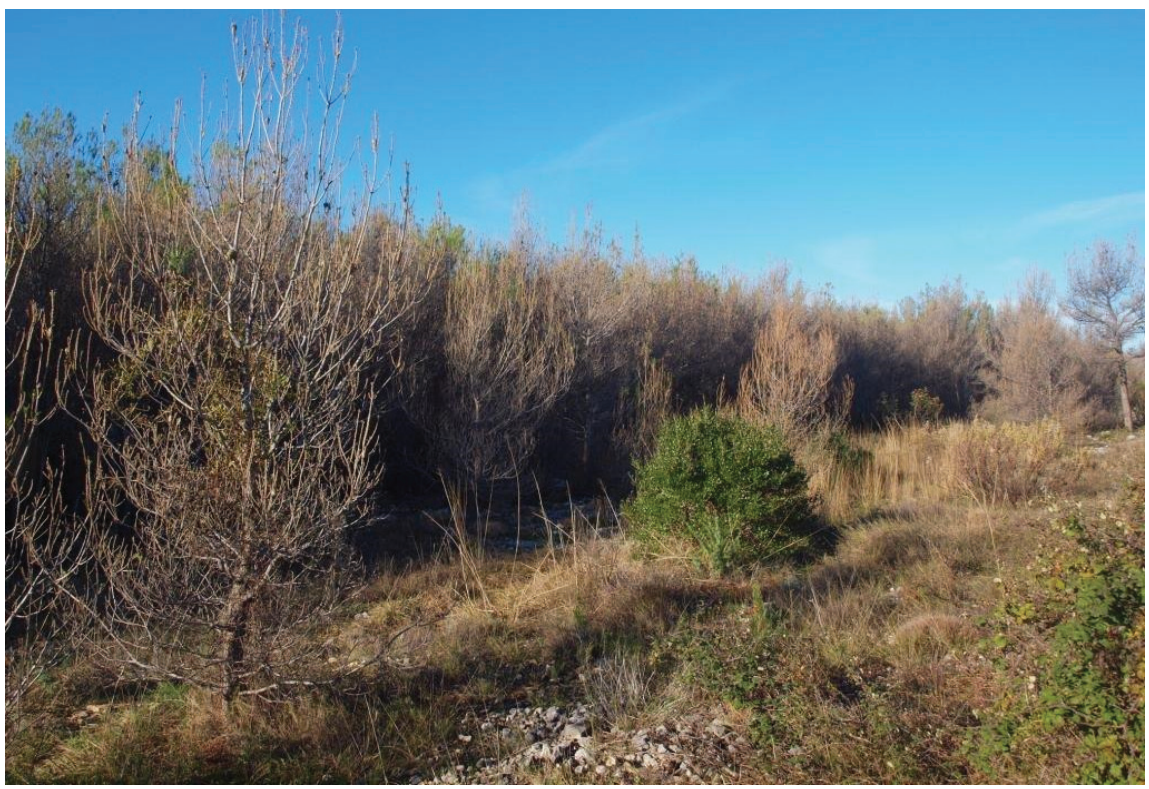

FIGURE 1. Dendrolimus pini outbreak in 2014 in Skradin, Šibenik. 
and Evolution at Faculty of Biology, University of Warsaw, Poland, for molecular identification.

\section{Outbreak in Dugi otok}

After the inspection of the protected area of Telašćica Nature Park on Dugi otok, Croatia, in August 2017, around 150 ha of an Aleppo pine forest were found under the attack of $D$. pini, 30 ha out of which were totally defoliated. The same approach of population assessment was applied for the estimation of this population. Again, $12 \mathrm{~m}^{2}$ of soil surface was sampled and the average number of larvae per square meter was assessed within the wooden frames.

In August 2017, 300+ larvae, and in September 2017, around 600 live and visually healthy $3^{\text {rd }}$ and $4^{\text {th }}$ larval instars were collected from Aleppo pine branches, trunks and the ground around trees in the infested area. Larvae were transferred to the Laboratory for Entomological Analysis in the Croatian Forest Research Institute, where they were incubated under laboratory conditions ( $\left.L: D=16: 8,23 \pm 1^{\circ} \mathrm{C}\right)$. They were checked on a daily basis for the mortality and appearance of parasitoid larvae or fungi mycelium on cadavers, and were daily fed with fresh Aleppo pine needles.

Emerging parasitoids were counted, collected and sent to Hans-Peter Tschorsnig, Staatliches Museum für Naturkunde, Stuttgart, Germany, for the identification. Sporulating white mycelium on dead individuals was microscopically examined for the morphological taxonomical identification.

\section{RESULTS}

During the $D$. pini population assessment in Skradin, 306 larvae were found on $12 \mathrm{~m}^{2}$, which means that the average number of larvae was 25.5 larvae per $\mathrm{m}^{2}$. Since far more than 10 larvae per $\mathrm{m}^{2}$ were found, the conclusion was that the outbreak level has been exceeded in this area, which would trigger the necessity for active suppression measures, if entomopathogenic fungus B. bassiana had not occurred in a large number of cases.

From 306 specimens collected and taken for further examination, morphological and molecular analyses confirmed the presence of entomopathogenic fungus $B$. bassiana on 301 dead caterpillars, i.e. $98.4 \%$ of the population. It was also found that one part of the population overwintered in the crown and was not attacked by $B$. bassiana, but during the control of the overwintering larvae in spring 2015, a new population collapse was recorded on the larvae infected with B. bassiana (Figure 2), while the Aleppo pine trees after full defoliation completely recovered (Figure 3).

The results from Dugi otok population estimation revealed that the average number of larvae per $\mathrm{m}^{2}$ was 21 , which again exceeded the known critical numbers for $D$. pini population, clearly visible in the field by total defoliation of Aleppo pines (Figure 4). In this case, larval infection with B. bassiana was low, and was recorded on around $1 \%$ of sampled larvae.

Parasitism rate on larvae collected in August was 2.8\%, and it reached $5.6 \%$ on those collected in September. On average, 3 days after the caterpillar's death, parasitoid dipteran larvae were leaving its host and pupating. It took further 10 days on average for the adult flies to emerge. All

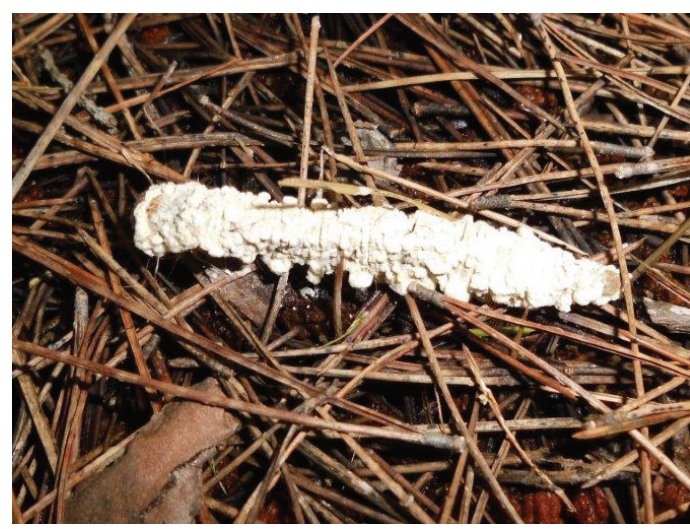

FIGURE 2. Dendrolimus pini larva covered with white mycelium of Beauveria bassiana fungus found on the soil surface.

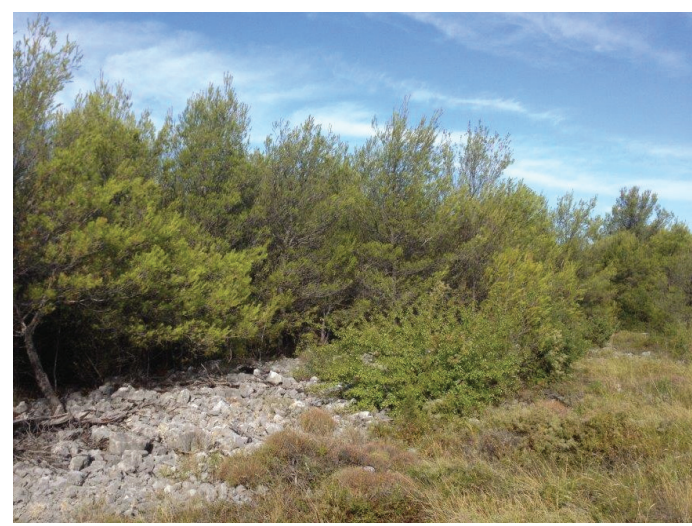

FIGURE 3. Recovered Aleppo pine stand after Dendrolimus pini defoliation and Beauveria bassiana infestation on overwintering larvae in 2015 in Skradin, Šibenik.

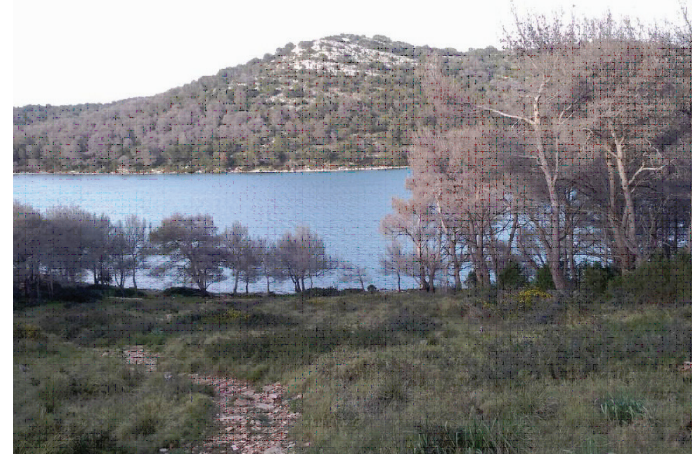

FIGURE 4. Dendrolimus pini outbreak in 2017 around Salt Lake, Telašćica Nature Park, Dugi otok. 
of the parasitoid individuals were identified as polyphagous tachinid fly Drino inconspicua Meigen (Diptera: Tachinidae).

The occurrence of superparasitism was recorded in 9 cases from $D$. pini larvae collected in September, where more than 2 parasitoid dipteran larvae emerged from one infested D. pini individual. From 5 D. pini individuals 2 of parasitoid dipteran larvae emerged, from 3 of them 3 parasitoid larvae emerged, and in one case there were 4 parasitoid larvae emerged from one $D$. pini individual.

\section{DISCUSSION AND CONCLUSIONS}

This research confirmed several unusual phenomena. Apart from the fact that Mediterranean Croatia does not represent the optimal area for the appearance of $D$. pini, Aleppo pine is not its primary host [3] and so far we had not witnessed an outbreak case. Another unusual phenomenon is the exceptionally high mortality of the overwintering $D$. pini larvae after Aleppo pine defoliation in the vicinity of Skradin.

In most cases it is hard to explain what triggers a certain outbreak, and why it happens in a specific time, place and level of severity. According to Lesniak [13], for the rapid spread of $D$. pini the most significant are the meteorological conditions, in terms of higher mean annual temperatures (particularly those during autumn and winter), lower wind velocities, less precipitation, fewer days with snow cover, greater duration of summer and vegetation season, and higher frequency of dry months. The results of his research also suggested that abiotic factors do not affect the pine moth directly, but rather the pine moth population dynamics indirectly, through the host plant.

In addition, high population density of $D$. pini can also be promoted by higher sunshine duration. Increased sunshine hours have a positive effect on egg development, as well as on larvae vitality due to the increase of feeding intensity. Higher survival rate as a result of earlier hibernation ending under favorable climatic conditions means avoiding certain risks related to overwintering in the soil (e.g. infestation with soilborne fungi or bacteria) and can also be attributed to higher daily sun duration [14].

Skradin and Dugi otok are located in the middle of the Mediterranean region of Croatia (Figure 5), where hot-summer Mediterranean climate dominates, and is characterized by rainy winters and dry summers.

According to Croatian Meteorological and Hydrological Service, the year 2014 in Skradin was extremely warm and wet, with an extremely warm winter and higher precipitation than usual in autumn and winter. Dugi otok climate in 2017

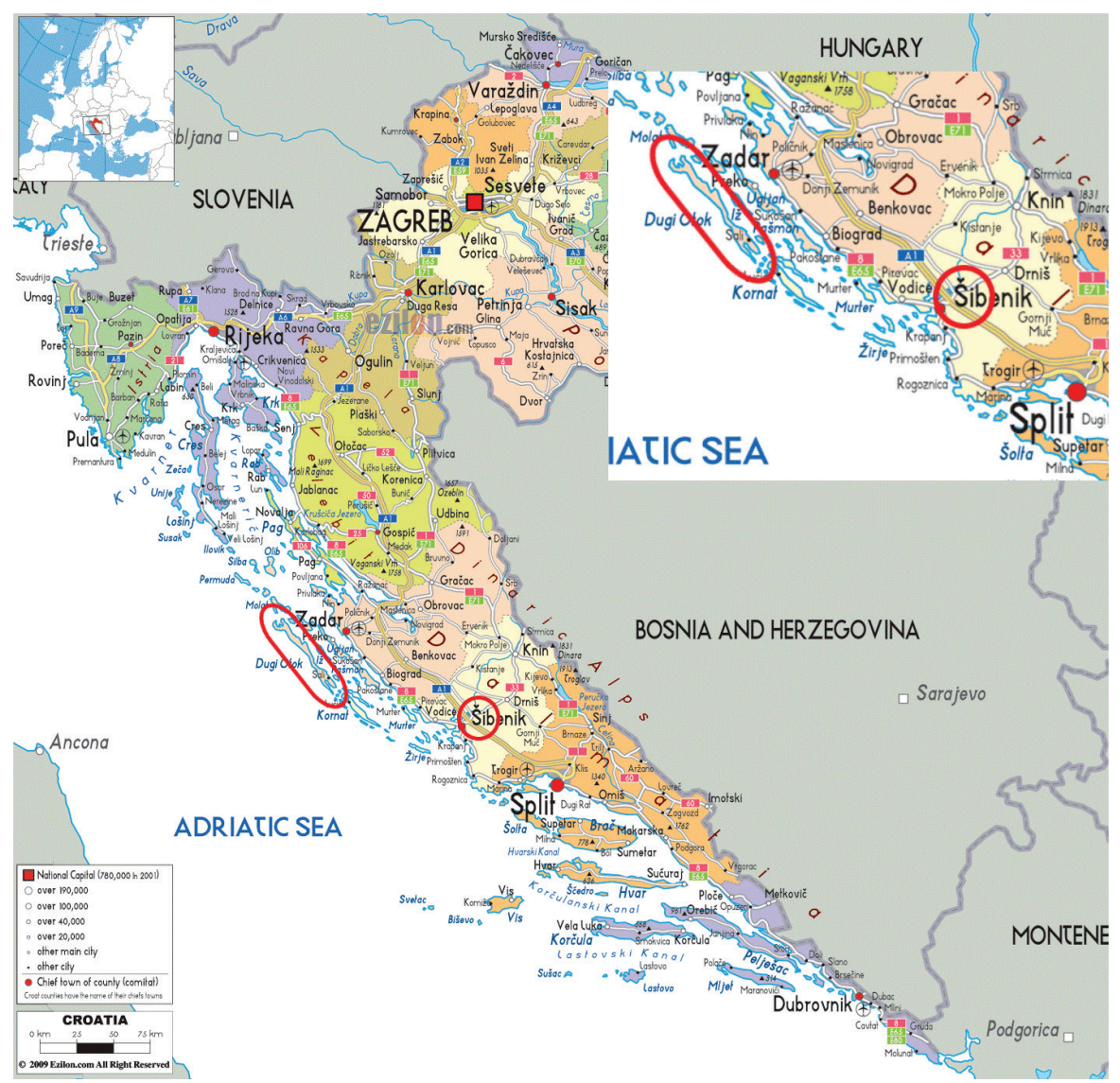

FIGURE 5. Map of Dendrolimus pini outbreak locations. 
was characterized by extremely warm weather with normal precipitation, but with extremely dry summer. In both cases we can conclude that extremely warm weather probably had a great impact on mass appearance of $D$. pini. Furthermore, the fact that both examined sites are dominated by monotypic Aleppo pine stands and that trees grown in such vegetation composition often do not possess the evolutionary developed ecological defense mechanisms to tolerate outbreaks of defoliators [15] should also be taken into account.

The role that natural antagonists played during these two mass outbreaks demonstrated their importance and posed some new questions. These relate to the possible mechanisms and triggers for the increase and breakdown of insect populations, such as weather conditions, natural enemies and diseases, lack of variability in forest composition or climate change.

In the case of Skradin, unusually high infestation of hibernating larvae with entomopathogenic fungus $B$. bassiana on the soil surface $(98.4 \%)$ resulted in steep breakdown of $D$. pini population. The only comparably known collapse of some insect outbreak due to entomopathogenic fungi in Croatia is known in the case of gypsy moth (Lymantria dispar L.), where highly infectious fungal pathogen Entomophaga maimaiga Humber, Shimazu \& R.S. Soper (Entomophthorales, Entomophthoraceae) caused death of thousands of $L$. dispar larvae [16]. In the case of Dugi otok B. bassiana appeared on dead $D$. pini larvae, but only in $1 \%$ of sampled larvae. The trigger for unusually high infestation of B. bassiana in Skradin probably lies in very wet conditions, which was not the case in Dugi otok, and therefore higher B. bassiana infection rates were not recorded. Larger numbers of larvae were infected with parasitoid $D$. inconspicua, with $5.6 \%$ of population being parasitized during the second larval sampling in September 2017. D. inconspicua is a polyphagous tachinid fly common in Europe and northern Africa. As a generalist parasitoid, it parasitizes various lepidopteran and several diprionid species feeding on a wide range of coniferous and deciduous trees. A few minutes after the deposition of eggs on the surface of host larvae, the tachinid larvae hatch and bore through the host integument. After 9-14 days, $3^{\text {rd }}$ instars of $D$. inconspicua hatch from the host and pupate in the ground, and after 2-3 weeks, adult flies emerge [17-19]. In Croatia, this species was formerly found in Krka National Park, Skradin [20].

This research describes the first outbreaks and population collapse reported on $D$. pini so far in Croatia and might act as good reference point for future studies. At the same time it is restricted to a more accurate prediction of possible similar event that could occur in future. Wider area of the mass appearance of $D$. pini that was in focus through this research should be regularly monitored and its evaluation should not be left out.

\section{Acknowledgments}

We would like to thank Nikola Zorić, Ivana Mihaljević, Anica Dietz, Ivan Lukić and Blaženka Ercegovac for their help during field and laboratory work, and Valter Floigl for providing us with information and assisting in the field when needed. We would also like to thank prof. dr. sc. Cezary Tkaczuk for morphological confirmation of Beauveria basssiana and for connecting us with dr. Marta Wrzosek from Department of Molecular Phylogenetics and Evolution at Faculty of Biology (University of Warsaw, Poland), together with her team who did molecular identification, and we would like to thank them for that. Also, we would like to acknowledge dr. Hans-Peter Tschorsnig from Staatliches Museum für Naturkunde (Stuttgart, Germany) for the identification of tachinid Drino inconspicua. This research has been fully supported by the Diagnostic and Prognostic Service (IPP) of Croatian Forest Research Institute (Jastrebarsko).

\section{REFERENCES}

1. BJÖRKMAN C, LINDELÖW A, EKLUND K, KYRK S, KLAPWIJK MJ, FEDDERWITZ F, NORDLANDER G 2013 A rare event - an isolated outbreak of the pine-tree lappet moth (Dendrolimus pini) in the Stockholm archipelago. Entomol Tidskr 134 (1-2): $1-9$

2. SIERPINSKA A 1998 Towards an integrated management of Dendrolimus pini L. In: McManus ML, Liebhold AM (eds) Proceedings: Population Dynamics, Impacts, and Integrated Management of Forest Defoliating Insects. USDA Forest Service General Technical Report NE-247, pp 129-142

3. RAY D, PEACE A, MOORE R, PETR M, GRIEVE Y, CONVERY C, ZIESCHE T 2016 Improved prediction of the climate-driven outbreaks of Dendrolimus pini in Pinus sylvestris forests. Forestry 89 (2): 230-244. DOI: https://doi.org/10.1093/ forestry/cpw007

4. LE MELLEC A, MICHALZIK B 2008 Impact of a pine lappet (Dendrolimus pini) mass outbreak on $\mathrm{C}$ and $\mathrm{N}$ fluxes to the forest floor and soil microbial properties in a Scots pine forest in Germany. Can J For Res 38 (7): 1829-1841. DOI: https://doi. org/10.1139/X08-045
5. HYDÉN N 2006 Dendrolimus pini tallspinnare. In: Nationalnyckeln till Sveriges flora och fauna. Fjärilar: Ädelspinnare-tofsspinnare. Lepidoptera: LasiocampidaeLymantriidae. ArtDatabanken, SLU, Uppsala, Sweden, pp 135-137

6. MOORE R, COTTRELL J, A'HARA S, RAY D 2017 Pine-tree lappet moth (Dendrolimus pini) in Scotland: Discovery, timber movement controls and assessment of risk. Scott For 71 (2): 34-43

7. KOLK A, STARZYK JR 1996 The Atlas of Forest Insect Pests. The Polish Forest Research Institute. Multico Warszawa, Poland, $705 \mathrm{p}$

8. RITTER F 1929 Die in Deutschlands Waldungen aufgetretenen schädlichen Insekten. Ein Literaturnachweis für die Jahre 1449-1926. Z Angew Entomol 14: 561-563

9. SCHÖYEN WM 1880 Om furuspinderens (Eutrichia pini) optraeden i Norge i aarene 1812-1816. Entomol Tidskr 1: 3942

10. MYHRWOLDT AK 1902 Om Furuspinderen (Bombyx pini, Gastropacha pini). Tidskr Skogbrug 10: 320-333 
11. MEWES J 1903 Tallspinnaren. En hotande fara förvåra skogar. Ent Tidskr 24: 61-64

12. FORSSLUND KH 1940. Ett massuppträdande av tallspinnaren $\mathrm{i}$ Värmland. Skogen, $15 \mathrm{p}$

13. LESNIAK A 1976 Climatic and meteorological conditions of the pine moth (Dendrolimus pini L.) outbreaks. Ekol Pol 24 (4): 515-547

14. HENTSCHEL R, MÖLLER K, WENNING A, DEGENHARDT A, SCHRÖDER J 2018 Importance of Ecological Variables in Explaining Population Dynamics of Three Important Pine Pest Insects. Front Plant Sci 9: 1667. DOI: https://doi.org/doi. org/10.3389\%2Ffpls.2018.01667

15. PRICE PW, BOUTON CE, GROSS P, MCPHERON BA, THOMPSON JN, WEIS AE 1980 Interactions among three trophic levels: influence of plants on interactions between insect herbivores and natural enemies. Annu Rev Ecol Syst 11: 41-65. DOI: https://doi.org/10.1146/annurev.es.11.110180.000353
16. HRAŠOVEC B, PERNEK M, LUKIĆ I, MILOTIĆ M, DIMINIĆ D, FRANJEVIĆ M, HAJEK A, LINDE A, PILARSKA D 2013 First record of the pathogenic fungus Entomophaga maimaiga Humber, Shimazu, and Soper (Entomophthorales: Entomophthoraceae) within an outbreak populations of Lymantria dispar (Lepidoptera: Erebidae) in Croatia. Period Biol 115 (3): 379-384

17. WEBBER RT 1932 Sturmia inconspicua Meigen, a tachinid parasite of the gypsy moth. J Agric Res 45: 193-208

18. HERTING B 1960 Biologie der westpalaarktischen Raupenfliegen (Dipt., Tachinidae). Monogr Angew Entomol 16: 1-188

19. ALTENKIRCHW, HUANG P 1986Zur Prüfung der unerwünschten Nebenwirkungen von Pflanzenbehandlungsmitteln auf Raupenfliegen (Diptera, Tachinidae). Nachr bl Dtsch Pflanzenschutzd 38 (7): 97-99

20. TSCHORSNIG HP 2017 Preliminary host catalogue of Palaearctic Tachinidae (Diptera). http://www.nadsdiptera. org/Tach/WorldTachs/CatPalHosts/Cat Pal tach hosts Ver1.pdf 